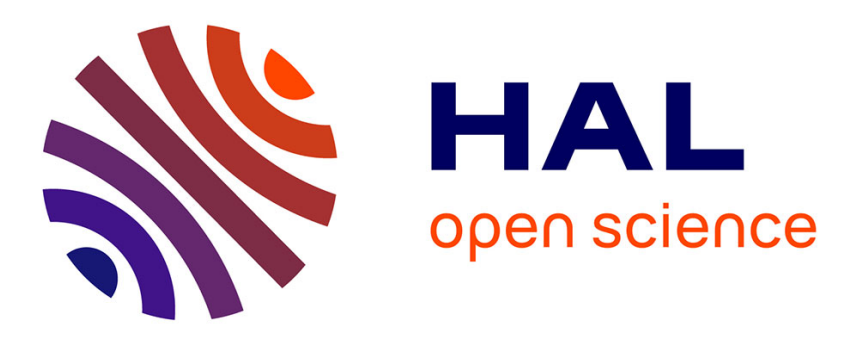

\title{
The educational attainment of the second generation in Germany
}

Cornelia Kristen, Nadia Granato

\section{To cite this version:}

Cornelia Kristen, Nadia Granato. The educational attainment of the second generation in Germany. Ethnicities, 2007, 7 (3), pp.343-366. 10.1177/1468796807080233 . hal-00571881

\section{HAL Id: hal-00571881 \\ https://hal.science/hal-00571881}

Submitted on 1 Mar 2011

HAL is a multi-disciplinary open access archive for the deposit and dissemination of scientific research documents, whether they are published or not. The documents may come from teaching and research institutions in France or abroad, or from public or private research centers.
L'archive ouverte pluridisciplinaire HAL, est destinée au dépôt et à la diffusion de documents scientifiques de niveau recherche, publiés ou non, émanant des établissements d'enseignement et de recherche français ou étrangers, des laboratoires publics ou privés. 
Copyright $\odot$ SAGE Publications 2007 (Los Angeles, London, New Delhi and Signapore) 1468-7968 Vol 7(3): 343-366;080233

DOI:10.1177/1468796807080233

http://etn.sagepub.com

\title{
The educational attainment of the second generation in Germany
}

Social origins and ethnic inequality

CORNELIA KRISTEN

University of Leipzig, Germany

\section{NADIA GRANATO}

Institute for Employment Research of the German Federal Employment Agency

\begin{abstract}
Using the German Microcensus, we study second-generation immigrants' educational attainment in Germany, focusing on the descendants of classic labour migrants. Our results show that educational outcomes in terms of attending or completing the highest schooling track leading to the Abitur vary considerably among different ethnic groups. Second-generation young adults, in particular Turks and Italians, experience pronounced disadvantages in comparison to their German peers. The central question in this context is to what extent ethnic stratification in the German school system is related to educational and social background. Our findings suggest that ethnic disadvantages primarily result from social rather than from specific ethnic inequalities, since initial differences in the chances of attaining the Abitur disappear after considering educational and social origin, the only exception being Italian young adults.
\end{abstract}

KEYWORDS education $\bullet$ immigrants $\bullet$ social background

\section{INTRODUCTION}

Ethnic educational inequality is a widespread empirical phenomenon, characterizing numerous schools systems throughout the world. In Germany too, these differences are very pronounced. They are reflected in measures of attainment (Baumert and Schümer, 2001; Schwippert et al., 2003, 2004; 
Stanat, 2003, 2006; Müller and Stanat, 2006), teacher assessments (Bos et al., 2004; Kristen, 2006), transition rates (Bos et al., 2004), track placement (Alba et al., 1994; Haisken-DeNew et al., 1997), and eventually in the qualifications achieved (Konsortium Bildungsberichterstattung, 2006). While members of the second generation attain better results than those of the first generation, compared to their German age peers without a migration background, children of immigrants still experience considerable disadvantages.

Without doubt, educational attainment is of key importance for the integration of immigrants and their descendants. As for the native-born population, education substantially shapes immigrants' labour market outcomes (Granato and Kalter, 2001; Kalter and Granato, forthcoming), as well as the subsequent generation's educational performance (Alba et al., 1994; Müller and Stanat, 2006). A German peculiarity, however, concerns the strength of these linkages which, as comparative mobility research has demonstrated, are more pronounced than in other countries (Erikson and Goldthorpe, 1992; Müller et al., 1998). In other words, not only in general is the education of the second generation essential for their structural integration but probably even more so in a context in which educational attainment is an especially strong predictor of labour market success and children's schooling outcomes.

For various countries it has been shown that ethnic disparities in education are largely the result of differences in educational and social background and, accordingly, are a matter of social rather than of specific ethnic inequalities (Vallet and Caille, 1999; Hustinx, 2002; Kao and Thompson, 2003: 431; Marks, 2005). While in some contexts this seems to be almost entirely the case, in others, ethnic differences persist after taking parental education and social origin into account. The finding that ethnic educational inequality is primarily due to differences in social background applies to Germany as well (Baumert and Schümer, 2001: 378; Kristen and Granato, 2004) but, depending on the performance indicator and the immigrant group under consideration, ethnic disadvantages do not always vanish completely (e.g. Alba et al., 1994; Müller and Stanat, 2006). In view of these findings, we take a closer look at ethnic stratification in the German school system and investigate to what extent the educational attainment of the second generation is related to differences in educational and social origin.

The article is structured as follows. First, we provide information on the German context regarding its school system as well as the main immigrant groups. In order to account for ethnic educational disadvantages, we then consider both processes of social class reproduction as well as mechanisms that apply in particular to immigrant families in Germany. Thereafter, using the German Microcensus (GMC), we investigate ethnic differences in education, focusing on the educational performance of second generation 
Turks, (ex)Yugoslavs, Italians, Greeks, Spaniards and Portuguese. Starting with some descriptive findings on ethnic variation in the completion of upper secondary education, we continue with multivariate analyses that focus on the impact of social background on the second generation's educational attainment. Finally, we summarize the main results and discuss the questions that remain unanswered.

\section{THE GERMAN CONTEXT}

In Germany, after four years of comprehensive education in primary schools, the first educational transition into three different tracks of secondary education follows (Anweiler, 1996; Cortina et al., 2003). While 'Hauptschule' (general elementary education, grades 5-9, age range approximately 10-15) leads to a minimum qualification, 'Realschule' (general intermediate education, grades 5-10, age range approximately 10-16) leads to a medium-level qualification. Both tracks have traditionally constituted the preparation for an apprenticeship, even if typically for different realms of apprenticeship. In contrast, the 'Gymnasium' (grades 5-13, age range approximately 10-19), with the 'Abitur' (maturity certificate), traditionally leads to university studies.

Compared to other countries, Germany's school system is highly stratified (Allmendinger, 1989). Students are sorted early on into different educational tracks that lead to distinct qualifications, with the differences between these qualifications being well recognized in the labour market (Müller and Shavit, 1998: 10). Upon the completion of upper secondary education, however, the German system of higher education is relatively less stratified, suggesting that the options for those who 'made it' and leave school with the Abitur are increased (Allmendinger, 1989: 237). In other words, the central matter for educational inequality in the German context seems to be whether individuals enter and accomplish one of the more demanding forms of secondary schooling. In our empirical study, we will focus on this distinction and investigate whether individuals attend or complete the highest German schooling track.

With rising numbers of immigrants and their children, ethnic differences in education are becoming an increasingly important issue in Germany. According to a recent report of the Federal Statistical Office, nearly 19 percent of the population have a migration background of some sort (Statistisches Bundesamt, 2006: 73-9). Apart from this data source, which for the first time includes detailed information on immigration background, available statistics usually identify different ethnic minority groups according to citizenship and therefore underestimate the share of immigrants and their children. 
Considering Germany's post-war immigration history, one can distinguish roughly four groups that make up today's population of immigrants and their descendants. These are the classic labour migrants and their families, ethnic Germans (i.e. individuals with German ancestry from Eastern European states, the so-called 'Aussiedler'), asylum seekers and refugees, as well as recent labour migrants from Eastern Europe (Sachverständigenrat für Zuwanderung und Integration, 2004; Kalter and Granato, forthcoming). In this article, we focus on the group of classic labour migrants who, starting in the late 1950s, have been recruited mainly from Turkey, former Yugoslavia, Italy, Greece, Portugal, and Spain to fill shortages of labour in the lower and less-qualified sectors of the German economy, resulting in a strongly negatively selected inflow (Kalter and Granato, forthcoming). At 56 percent, classic labour migrants and their descendants still comprise the largest proportion among foreign nationals in Germany; the Turkish share taken alone amounts to 26 percent (Bundesamt für Migration und Flüchtlinge 2006: 82).

\section{ACCOUNTING FOR ETHNIC DIFFERENCES IN EDUCATION}

In general, educational outcomes can be conceived as the result of a continuous process of developing and accumulating school-relevant skills that stretches from birth onwards throughout the different stages of the pre-school and school career. Specific conditions associated with an individual's social and ethnic background not only shape this process, but also may influence the educational decisions that individuals make at different transition points in their educational careers (Boudon,1974). With regard to the completion of the highest schooling track in Germany, the Abitur, this would require the investigation of the transition from primary to secondary schooling, as well as the decision of whether to enter the most demanding educational path after the completion of one of the two lower tracks of secondary education. This undertaking is beyond the scope of this article, both theoretically as well as with respect to the currently available data. Nonetheless, in this section we attempt to address briefly the mechanisms that may be responsible for the intergenerational transmission of ethnic disadvantages in education. In view of the central finding that ethnic differences in educational attainment are above all an issue of social inequality, we start with arguments that centre on the processes by which social and educational origin affect children's school achievement and thereafter continue with the question of why social background taken alone may be insufficient to account fully for the disadvantages the second generation experiences.

Probably the most important argument connecting social background 
with children's educational attainment refers to differences in the distribution of resources and characteristics that are relevant for school success. That is, childhood conditions systematically vary with the financial, cultural and social resources available within the family and the immediate environment. For example, better educated parents can provide more qualified help with the learning of cognitive and other types of skills that improve performance in schools in terms of test results or teacher-assigned grades (Erikson and Jonsson, 1996: 26). In addition, such parents have a better strategic knowledge about the educational system, which puts them in a favourable position at the main educational transitions (Kristen, 2005). They may have a better understanding when selecting among tracks and may have more precise knowledge about the grades necessary for making a certain transition or about other requirements (and therefore are able to intervene in time when difficulties arise - even long before the actual transition takes place). In sum, for families with more favourable resources, it is much easier to continuously support and secure their offspring's educational career, whereas for those in a less beneficial position it is more difficult to pursue similarly promising and efficient educational strategies.

In addition to these family-based differences, the general resources argument can be applied to educational resources available outside the family as well. For example, social disadvantages in education may be further reinforced by contextual conditions that influence scholastic achievement, such as differential learning environments in schools due to social (and ethnic) segregation (Portes and Hao, 2004; Dronkers and Levels, 2006; Stanat, 2006).

A second group of arguments concerns class differences in educational aspirations, with the higher social classes favouring the more demanding and prestigious qualifications (Boudon, 1974; Gambetta, 1987; Erikson and Jonsson, 1996; Breen and Goldthorpe, 1997; Esser, 1999). According to Boudon (1974), when choosing between different educational alternatives, families from higher classes have more to lose from not selecting the most demanding educational track because they risk social demotion, whereas children from lower classes do not descend if they attend one of the less ambitious tracks. In the German context, parental aspirations may be particularly relevant at the first educational transition where individuals decide whether or not to pursue the most challenging track, which leads to the Abitur.

Institutional arrangements may also shape the degree to which educational and class disadvantages are transmitted across generations. One prominent example is the timing of the first educational transition. At early decision points, there is still little actual information about a child's ability. In these instances, choosing a more ambitious educational track might be perceived as more risky by members of the lower social classes because, compared to the higher social classes, these parents may feel less 
confident that they can provide qualified help if needed (Erikson and Jonsson, 1996: 36). At a later point in the school career, however, when more information is available, they may feel more confident about the chances of their child's success in a higher track. In Germany, where the first educational transition from primary to secondary schooling takes place after only four years of comprehensive primary schooling, this early hurdle has been frequently identified as a crucial factor in reproducing social inequality (Allmendinger, 1989).

So far, the reasoning linking social origins to educational outcomes applies equally to families with and without a migration background. Since classic labour migrants in Germany were negatively selected in terms of their educational and social origin, social disadvantages may partly account for the observed educational disadvantages of the second generation. However, children of immigrants may face additional problems. To account for these we start once more with the general resources argument, this time considering an additional aspect. That is, the educational resources that are required for the development of school-relevant skills as well as for making advantageous transitions are to some extent specific to the particular educational setting. Therefore, immigrant parents who grew up and attended school in a different context would not have acquired them through their own school careers, and the specific resources they bring from their country of origin may not prove as useful in a different school system (Chiswick, 1978; Chiswick and DebBurman, 2004). Hence, restricted transferability of origin-specific educational resources may affect immigrant families' ability to make educational investments. A prime example is language proficiency. Educational knowledge about the functioning of the school system is also an important characteristic that cannot easily be transferred from one context to another. Therefore, even at the same level of parental education, if acquired elsewhere, immigrants may be at a disadvantage. Obviously, this reasoning applies in particular to the first generation but it may also affect the education of the second generation who, especially at younger ages, very much rely upon parent's knowledge and school support. In particular, language acquisition may be delayed in contexts in which large numbers of non-native speakers, often of low socioeconomic status, concentrate together (Caldas and Bankston, 1998: 554).

A second specific 'ethnic explanation' is discrimination. Discrimination in schools may involve teachers' perceptions and expectations, their assessments, or other kinds of behaviour. In principle, it may affect both educational transitions (e.g. via teacher recommendations) or, in more subtle ways, the development of students' competences (Ferguson, 1998; Schofield, 2006).

Third, it has been argued that educational aspirations in immigrant families may differ from those of the indigenous population (Kao and Tienda, 1995; Kao and Thompson, 2003: 422). However, rather than 
referring to ethnic disadvantages, aspirations may account for a group's exceptional educational success. In Germany, for example, the remarkable performance of Greek students has sometimes been associated with their pronounced educational motivation (Hopf, 1987).

Finally, institutional conditions may have an impact on the second generation's educational attainment as well. This consideration concerns both institutional regulations that apply to children of immigrants only, such as assigning them to special programmes, tracks or courses, as well as institutional rules that apply to all children, but that may have a differential impact on some groups. For example, an early timing of the first educational transition may not only affect the degree to which class disadvantages are transmitted across generations, but may be of additional importance for children of immigrants. They might need more time to catch up with their native-born peers because they speak another language at home or because it takes longer for them to become familiar with the school system.

Taken together, the various arguments summarized in this section may account for those ethnic differences in educational attainment that are not associated with social inequalities. We will now turn to the empirical question of whether these additional explanations are of relevance in the German school system, and if so to what extent.

\section{EMPIRICAL RESULTS: THE SECOND GENERATION'S EDUCATIONAL ATTAINMENT}

Using the GMC (Lüttinger and Riede, 1997), we investigate the education of the second generation in the German school system and inquire whether children of classic labour migrants attend or complete the highest schooling track. We pool information from years 1991-2004 (further details are provided in the Appendix).

Describing the level of educational attainment, we focus on young people aged 18 to 25 at the time of the GMC. Figure 1 illustrates educational outcomes with respect to upper secondary education separately for women and men. For each ethnic group, it shows the proportion of individuals who have accomplished the Abitur or are preparing for it. ${ }^{1}$

One common pattern for most groups is that women do better than men, with the exception of Italians and Portuguese. Concerning ethnic differences, Italians and Turks show the poorest performance, while the proportion of Greeks who aspire to, or have achieved, the Abitur is similar to their German peers. Second-generation Portuguese and Spaniards are somewhat less successful, but still they clearly outperform the remaining immigrant groups. The achievement of Yugoslavs comes next. However, it 


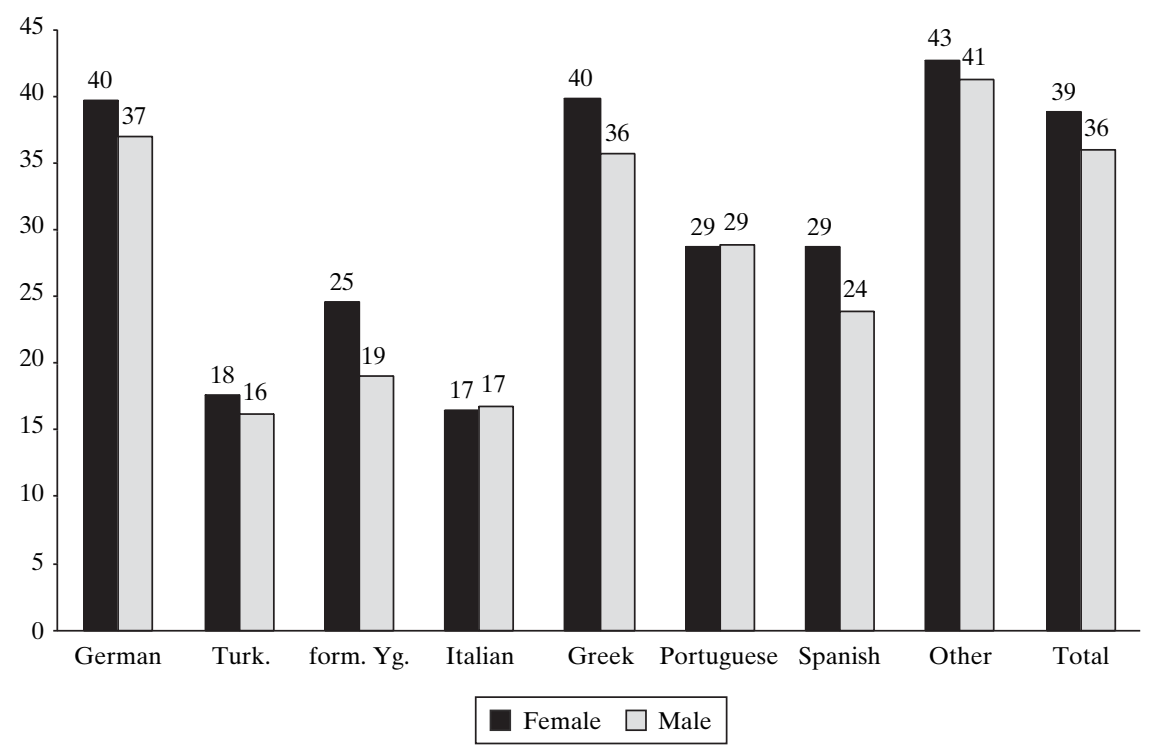

Figure 1 Percentage of Abitur by gender (second generation and Germans, age 18-25)

Number of cases by ethnic group: German, 361,988; Turkish, 10,088; former Yugoslavia, 3,218; Italian, 2,518; Greek, 1,494; Portuguese, 360; Spanish, 511; Other, 2,278.

Source: GMC 1991-2004, combined datasets, $n=382,455$.

differs for men and women: Yugoslav women outperform Italian and Turkish women, whereas Yugoslav men are closer to the attainment of Italians and Turks. All in all, the level of educational attainment visibly varies among the different ethnic groups and, except for the Greeks, the second generation experiences pronounced disadvantages in the German school system.

Figure 2 illustrates the changes over time. ${ }^{2}$ The German population displays a continuous increase in the proportion of young adults who aspire to, or have accomplished, the Abitur. The respective share among Greeks bounces around the German line, with large variations in 1995 and above all in 2004. ${ }^{3}$ For the remaining three groups of Turks, Yugoslavs and Italians, the graph shows a slightly positive trend over time, although the distance from the German educational level tends to amplify somewhat. By and large, educational attainment increases for all ethnic groups, but for Turks, Yugoslavs and Italians the rate of change seems to be smaller than for Germans.

The limited information available in the GMC means that we cannot directly address the mechanisms connected to specific ethnic disadvantages as outlined in the previous section. Instead, our account centres on the 


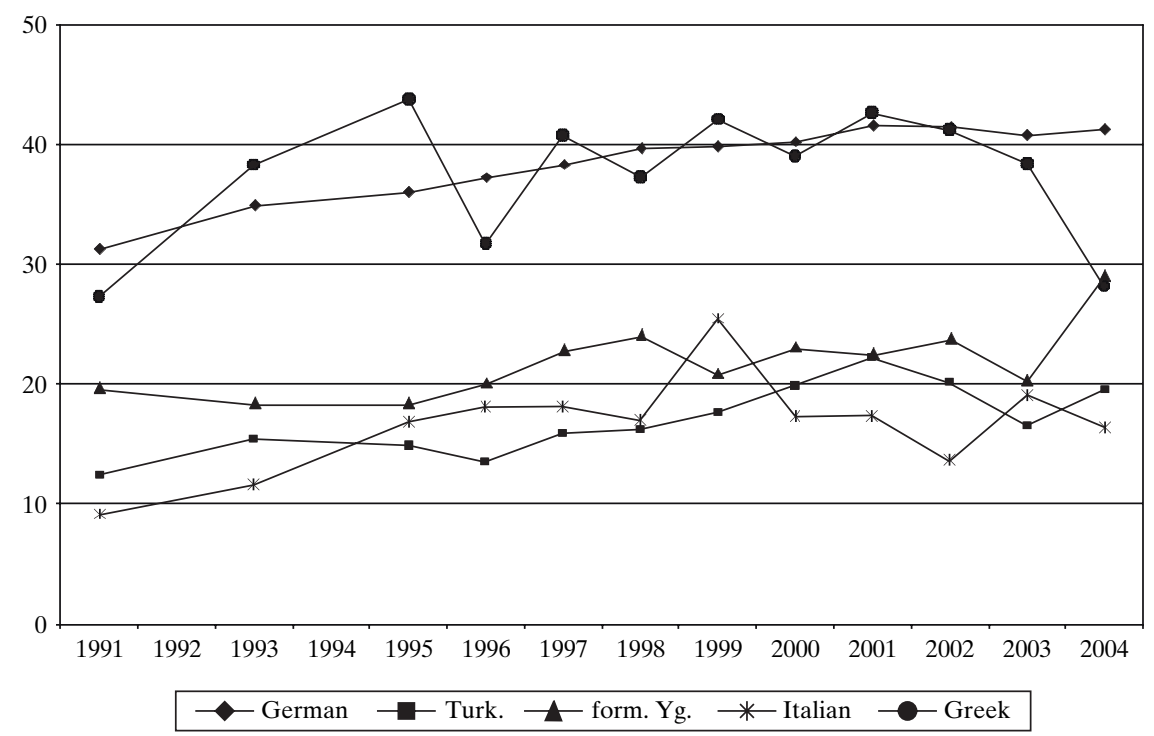

Figure 2 Percentage of Abitur by year (second generation and Germans, age 18-25)

Source: GMC 1991-2004, combined datasets.

impact of social background on second-generation educational attainment: To what extent is their performance related to differences in social background and to what extent do we need to consider mechanisms that apply specifically to the children of immigrants? Accordingly, as a next step, we study whether ethnic differences in the completion of the Abitur persist after controlling for parental educational and social origin. To address this question, we estimate several logistic regression models in which we proceed in a stepwise manner. In these analyses, we only include 18year-olds living in the parental home, because we have data both on their own educational achievements and on various characteristics of their families, such as parental education and occupation (further details are provided in the Appendix).

Figure 3 illustrates what happens to the initial ethnic disadvantages when taking the relevant background variables into account. (The full results of the logistic regressions are shown in Table A2 in the Appendix.) The odds ratios (i.e. the bars in Figure 3) identify for each ethnic group the relative chances of obtaining the Abitur (or being in the Abitur track) versus having completed a lower educational track and not preparing for the Abitur. Values below 1 indicate that the second generation's chances of achieving the Abitur are below those of Germans, while values above 1 point to relatively higher chances. 


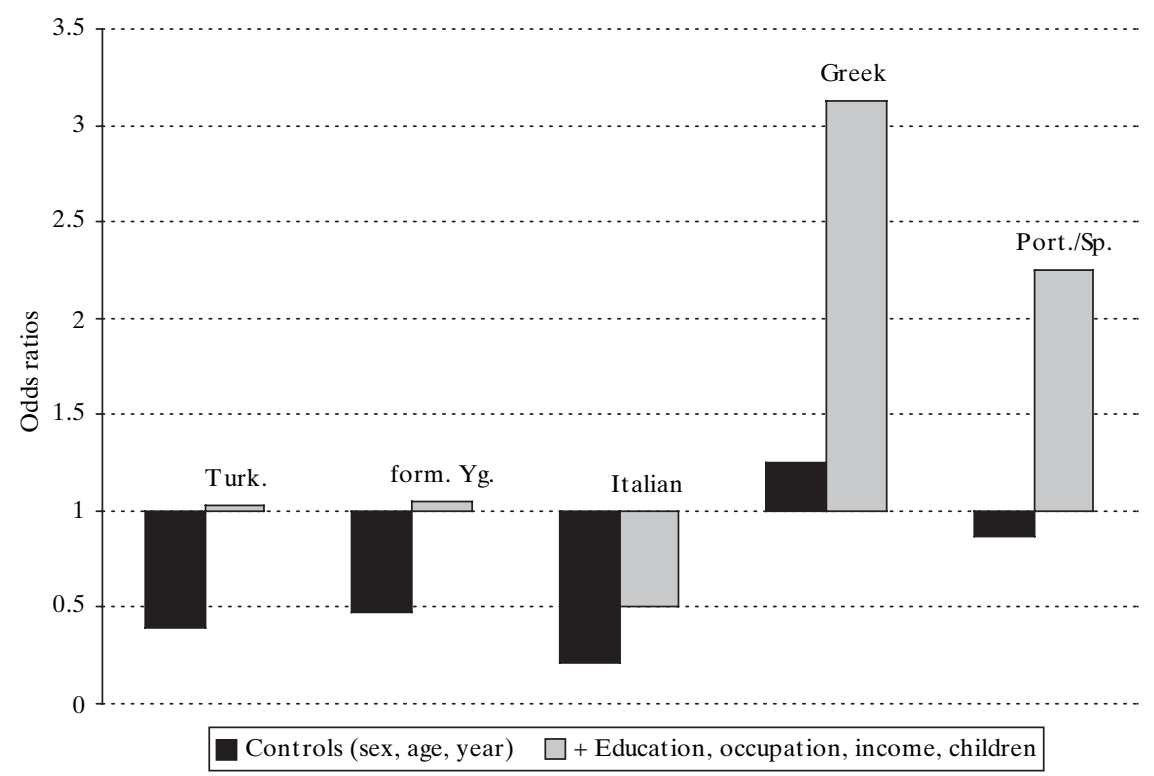

Figure 3 Relative chances of Abitur (second generation versus Germans, age 18)

Source: GMC 1991-2004, combined datasets, $n=39,933$.

The white bars in Figure 3 show that Turkish, former Yugoslav and especially Italian 18-year-olds are much less likely than Germans to pursue the track towards the Abitur, whereas Greek and Iberian young adults do not differ significantly from their German peers. The next step (model 2 in Table A2) takes account of social background. As expected, parents' educational attainment is of crucial importance to children's school success. In comparison to all other socioeconomic aspects included here, it has the largest impact on their achievement (not shown here). The higher the parental level of education, the better are young adults' chances of attending or completing the highest school track. Parents' occupational background and the financial resources available in the household also influence their offspring's performance. The more income and the higher the occupational status, the better are young adults' schooling outcomes. Figure 3 illustrates that the initial disadvantages for Turks, (ex)Yugoslavs and Italians strongly diminish when we control for these aspects of social background. For Turks and former Yugoslavs, these differences completely disappear. Only second-generation Italians still encounter disadvantages after taking account of social background. Greeks and Iberians, in contrast, who from the beginning have shown similar rates of participation, now clearly outperform their German peers. By and large, these results indicate 
that the story of the second generation's low educational performance in Germany is primarily one of negative selection in terms of parental education and social background.

In a final step, we investigate whether the second generation profits in a similar way to German 18-year-olds from their parents' education. As discussed above, the educational knowledge available in immigrant families may be less useful for school success if parents accomplished their educational careers elsewhere: for these parents, it may have been relatively more difficult to acquire the kind of knowledge necessary for a successful navigation of the German school system. This reasoning may apply in particular to families who live in environments in which this knowledge is not readily available, or to individuals who come from countries in which the school system differs very much from the German one. In these instances, it may take longer to become familiar with the new system. Again, with the information available in the GMC, it is not possible to study how the processes work, but at least we can investigate whether the second generation profits in a similar manner to Germans from their parents' education. For this purpose, we examine the interactions between nationality, parental education and their children's education (Model 3 in Table A2). ${ }^{4}$ The interaction turns out to be negative for all immigrant groups, but the coefficient is significant only for Turks. A negative interaction effect indicates that higher parental education does not improve the chances of their children reaching the Abitur as much for immigrants' descendants as it does for their German peers.

\section{CONCLUSION}

In this article, we studied the second generation's educational attainment in Germany, focusing on the descendants of classic labour migrants. Our empirical results in large part are consistent with previous findings on immigrant children's performance in the German school system. That is, educational outcomes in terms of attending or completing the highest schooling track leading to the Abitur vary considerably among different ethnic groups. Except for the Greeks, second-generation young adults, in particular Turks and Italians, at this stage in their school careers, experience pronounced disadvantages in comparison to their German peers. These differences, however, primarily result from social rather than from specific ethnic inequalities. Except for Italian 18-year-olds, initial differences in the chances of aspiring or having achieved the Abitur completely disappear after considering educational and social origin. Greeks and Iberians even outperform their German age peers. Accordingly, explanations that apply in particular to immigrant families, such as discrimination, are of minor 
relevance for explaining the second generation's relative disadvantages in the German school context. However, since parents' education, or rather the more or less favourable educational conditions associated with certain educational backgrounds, is crucial to children's school success, the educational attainment of immigrants' descendants may only improve slowly and over several generations.

Aside from these central findings, the result that the returns to parental education in terms of reaching the Abitur are significantly lower for secondgeneration Turks than for their German counterparts requires further consideration. Obviously, several interpretations are consistent with this finding. As already discussed, it might be because of differences in knowledge about the German school system. It may take longer for Turkish families to acquire this kind of profound educational knowledge because the Turkish school system differs significantly from the German one, or because this knowledge is not always readily available in the ethnically segregated environments in which children of Turkish origin frequently grow up. Another interpretation could be discrimination against bettereducated Turkish families, but in this case it would be necessary to elaborate further on the question as to why this assessment might be directed only towards Turkish students but not towards students from other immigrant groups. Since our analyses do not allow for conclusions about which of these alternative explanations accounts for the relatively lower returns to parental education in the Turkish group, understanding this finding needs further research. After all, it should be kept in mind that the crucial result for the group of Turkish 18-year-olds is that the relative disadvantages they experience in upper secondary education above all are due to the lower educational qualifications their parents have acquired in comparison to Germans.

Although our central results comply with those of other German studies on this subject, there are also differences. For example, after taking social origin and other relevant aspects into account, Müller and Stanat (2006) identify a persistent Turkish disadvantage in the reading performance of 15-year-olds. Also Alba et al. (1994), who analyse ethnic variation in the distribution over the three different secondary tracks, find persistent negative Turkish and Italian effects. However, these studies use different indicators of educational attainment and they focus on different stages in the school career and on different age groups. Consequently, it is difficult to compare our results with those somewhat divergent findings. Nonetheless, they illustrate that social origin taken alone is not always sufficient to account for the educational disadvantages certain immigrant groups experience at particular points in their school careers.

In our study, this result applies to second-generation Italians, who perform well below Germans of comparable educational and social origin. This group's disadvantage seems especially puzzling because Italian labour 
migrants were the first to be recruited in the late 1950s and thus have been exposed longer than any other group to the German school system. Sometimes it has been argued that during their school careers, Italian children stayed for longer periods in Italy and these interruptions may have hampered their educational advancement (ENAIP 1986: 18). However, so far, empirical evidence on this subject is rare (e.g. Alba et al., 1994: 232-3; Diehl, 2002).

Another 'ethnic puzzle' concerns the Greek students' exceptional school success. Overall, they attain results similar to Germans and after considering educational and social background they clearly outperform them. To account for this pronounced advantage, it has been suggested that Greek families may be more ambitious to do well in school and hence exhibit higher educational aspirations (Hopf, 1987). Also, the existence of Greek schools in Germany may contribute to this group's favourable performance (Alba et al., 1994). Aside from Greek instruction, these schools offer a familiar school setting. By attending a Greek school in Germany, students of Greek origin encounter an exceptional situation in which the specific educational resources their families bring from Greece, for example language skills or specific knowledge about the functioning of the school system, remain very useful. In contrast, we would expect that Greek students who attend German schools, just like other children of immigrants, profited less from their specific educational resources. If this reasoning applies, the positive Greek effect in our study would overestimate this group's performance in the German school system. To test this argument, however, it would be necessary to study Greek students' attainment separately in German and Greek schools, a task that is not feasible with the GMC.

Obviously, studying educational inequalities using the GMC has its limitations. One of the problems is that we could not distinguish between the three different tracks of secondary schooling and consequently our analyses were restricted to the highest German schooling track leading to the Abitur. It is entirely possible, and findings from other studies seem to suggest this, that the results might be somewhat different if we contrasted the medium with the lowest secondary track (e.g. Alba et al., 1994; Kristen, 2002; Birkner, 2005). Also with regard to future labour market prospects, this distinction is important, since relatively few Turkish and Italian young adults attain the Abitur. Moreover, with the information available, we were not able to investigate the nature of the linkages between social and ethnic origin and educational outcomes in more detail and, accordingly, the empirical study remained mainly descriptive.

Nevertheless, the GMC is an important large-scale data source for the study of ethnic educational inequalities in the German school system. It provides information on relevant characteristics such as educational attainment, ethnic origin and social origin (for those who still live in the parental 
household), and it includes sufficient numbers of cases to distinguish between different ethnic groups. Especially in a country like Germany, in which longitudinal information on educational careers is not available and in which large-scale cross-sectional student assessments have only very recently been introduced, the GMC will remain an important data source for studying the education of the second generation. In particular, the most recent survey of 2005 will provide new opportunities. The information on track attendance, as well as on other relevant characteristics, is still limited. However, for the first time it contains, aside from citizenship, additional indicators on migration background, and thus will allow for a more detailed study of the education of immigrants and their descendants in Germany.

\section{Notes}

1 For almost 5 percent of all respondents in this age group, information on educational attainment is missing. Another 1 percent has not yet finished general secondary education (i.e. grades 5-10) and for them information on the track attended is missing as well. These two categories have been omitted from the calculations in Figure 1.

2 For the Iberian group, i.e. Portuguese and Spanish respondents, the number of cases is too small to allow for a breakdown by year.

3 As with the Iberians, the Greek group is rather small (and declining in size), which might in part explain why the percentages change so much from one year to the next.

4 To build the interaction term we treat the CASMIN classification as a continuous variable.

\section{References}

Alba, Richard D., Johann Hande and Walter Müller (1994) 'Ethnische Ungleichheiten im deutschen Bildungssystem' (Ethnic inequality in the German school system), Kölner Zeitschrift für Soziologie und Sozialpsychologie 46(2): 209-37.

Allmendinger, Jutta (1989) 'Educational Systems and Labor Market Outcomes', European Sociological Review 5(3): 231-50.

Anweiler, Oskar (1996) 'Deutschland' in Oskar Anweiler (ed.) Bildungssysteme in Europa: Entwicklung und Struktur des Bildungswesens in zehn Ländern, pp. 31-56. Weinheim: Beltz.

Baumert, Jürgen and Gundel Schümer (2001) 'Familiäre Lebensverhältnisse, Bildungsbeteiligung und Kompetenzerwerb' (Family background, educational participation, and competence acquisition), in Jürgen Baumert, Eckhard Klieme, Michael Neubrand, Manfred Prenzel, Ulrich Schiefele, Wolfgang Schneider, Petra Stanat, Klaus-Jürgen Tillmann, Manfred Weiß (eds) PISA 2000: Basiskompetenzen von Schülerinnen und Schülern im internationalen Vergleich, pp. 323-407.Opladen: Leske \& Budrich.

Birkner, Elisabeth (2005) 'Ethnische Unterschiede am ersten Bildungsübergang' (Ethnic differences at the first educational transition), thesis, Leipzig University. 
Bos, Wilfried, Andreas Voss, Eva-Maria Lankes, Knut Schwippert, Oliver Thiel, and Renate Valtin (2004) 'Schullaufbahnempfehlungen von Lehrkräften für Kinder am Ende der vierten Jahrgangsstufe' (Teachers' transition recommendations at the end of the fourth grade), in Wilfried Bos, Eva-Marie Lankes, Manfred Prenzel, Knut Schwippert, Renate Valtin and Gerd Walther (eds) IGLU: Einige Länder der Bundesrepublik Deutschland im nationalen und internationalen Vergleich, pp. 191-228. Münster: Waxmann.

Boudon, Raymond (1974) Education, Opportunity, and Social Inequality. New York: Wiley.

Brauns, Hildegard and Susanne Steinmann (1999) 'Educational Reform in France, West-Germany and the United Kingdom: Updating the CASMIN Educational Classification', ZUMA-Nachrichten 44(23): 7-44.

Breen, Richard and John H. Goldthorpe (1997) 'Explaining Educational Differentials: Towards a Formal Rational Action Theory', Rationality and Society 9(3): 275-305.

Bundesamt für Migration und Flüchtlinge (2006) Migration, Asyl und Integration in Zahlen (Migration, asylum and integration in figures). Nürnberg: Bundesamt für Migration und Flüchtlinge.

Caldas, Stephen J. and Carl Bankston III (1998) 'The Inequality of Separation: Racial Composition of Schools and Academic Achievement', Educational Administrative Quarterly 34(4): 533-57.

Chiswick, Barry R. (1978) 'The Effect of Americanization on the Earnings of Foreign-Born Men', Journal of Political Economy 86(5): 897-922.

Chiswick, Barry R. and Noyna DebBurman (2004) 'Educational Attainment: Analysis by Immigrant Generation', Economics of Education Review 23(4): 361-79.

Cortina, Kai S., Jürgen Baumert, Achim Leschinsky, Karl Ulrich Mayer, Luitgard Trommer (2003) Das Bildungswesen in der Bundesrepublik Deutschland. Strukturen und Entwicklungen im Überblick (Germany's educational system: Structures and developments). Reinbek: Rohwolt.

Diehl, Claudia (2002) 'Die Auswirkungen längerer Herkunftslandaufenthalte auf den Bildungserfolg türkisch- und italienischstämmiger Schülerinnen und Schüler' (The impact of long-term visits to the country of origin on the educational success of turkish- and italian-origin students), Zeitschrift für Bevölkerungswissenschaft 27(2): 165-84.

Dronkers, Jaap and Mark Levels (2006) 'Social-Economic and Ethnic SchoolSegregation in Europe and Australia and Educational Achievement of MigrantPupils coming from Various Regions of Origins', paper presented at the Meeting of the ISA Research Committee on Social Stratification and Mobility 'Intergenerational Transmissions: Cultural, Economic or Social Resources?', May, Nijmegen, the Netherlands.

ENAIP (1986) 'Zur Situation italienischer Jugendlicher beim Übergang von der Schule ins Ausbildungs- und Beschäftigungssystem' (Italian youth at the transition from school to the vocational system and the labour market), Informationsdienst zur Ausländerarbeit 8(2): 17-20.

Erikson, Robert and John H. Goldthorpe (1992) The Constant Flux: A Study of Class Mobility in Industrial Countries. Oxford: Clarendon Press.

Erikson, Robert and Jan O. Jonsson (1996) 'Explaining Class Inequality in 
Education: The Swedish Test Case', in Robert Erikson and Jan O. Jonsson (eds) Can Education Be Equalized? The Swedish Case in Comparative Perspective, pp. 1-63. Stockholm: Westview Press.

Esser, Hartmut (1999) Soziologie. Spezielle Grundlagen, Band 1: Situationslogik und Handeln (Sociology. Volume 1: The logic of the situation and action). Frankfurt: Campus.

Ferguson, Ronald F. (1998) 'Teachers' Perceptions and Expectations and the Black-White Test Score Gap', in Christopher Jencks and Meredith Philips (eds) The Black-White Test Score Gap, pp. 273-317.Washington, DC: Brookings Institution.

Gambetta, Diego (1987) Were They Pushed or Did They Jump? Individual Decision Mechanisms in Education. Cambridge: Cambridge University Press.

Granato, Nadia and Frank Kalter (2001) 'Die Persistenz ethnischer Ungleichheit auf dem deutschen Arbeitsmarkt. Diskriminierung oder Unterinvestition?' (The Persistence of Ethnic Inequality in the German labour market: Discrimination or under-investment in human capital?), Kölner Zeitschrift für Soziologie und Sozialpsychologie 53(3): 497-520.

Haisken-DeNew, John P., Felix Büchel and Gert G. Wagner (1997) 'Assimilation and Other Determinants of School Attainment in Germany: Do Immigrant Children Perform as well as Germans?', Vierteljahreshefte zur Wirtschaftsforschung 66(1): 169-79.

Hopf, Diether (1987) Herkunft und Schulbesuch ausländischer Kinder: Eine Untersuchung am Beispiel griechischer Schüler (Origin and school attendance of foreign children: The example of greek students). Berlin: Max-Planck-Institut für Bildungsforschung.

Hustinx, Paul W.J. (2002) 'School Careers of Pupils of Ethnic Minority Background After the Transition to Secondary Education: Is the Ethnic Factor Always Negative?', Educational Research and Evaluation 8(2): 169-95.

Kalter, Frank and Nadia Granato (forthcoming) 'Educational Hurdles on the way to Structural Assimilation in Germany', in Anthony F. Heath and Sin Yi Cheung (eds) Unequal Chances: Ethnic Minorities in Western Labour Markets. Oxford: Oxford University Press for the British Academy.

Kao, Grace and Jennifer S. Thompson (2003) 'Racial and Ethnic Stratification in Educational Achievement and Attainment', Annual Review of Sociology 29: 417-42.

Kao, Grace and Marta Tienda (1995) 'Optimism and Achievement: The Educational Performance of Immigrant Youth', Social Science Quarterly 76(1): 1-19.

Konsortium Bildungsberichterstattung (2006) Bildung in Deutschland: Ein indikatorgestützter Bericht mit einer Analyse zu Bildung und Migration (Education in Germany: An indicator-based report on education and migration). Bielefeld: Bertelsmann.

Kristen, Cornelia (2002) 'Hauptschule, Realschule oder Gymnasium? Ethnische Unterschiede am ersten Bildungsübergang' (Hauptschule, Realschule or Gymnasium? Ethnic differences at the transition from primary to secondary schooling), Kölner Zeitschrift für Soziologie und Sozialpsychologie 54(3): 534-52.

Kristen, Cornelia (2005) School Choice and Ethnic School Segregation: Primary School Selection in Germany. Münster: Waxmann.

Kristen, Cornelia (2006) 'Ethnische Diskriminierung in der Grundschule? Die 
Vergabe von Noten und Bildungsempfehlungen' (Ethnic discrimination in primary schools? Grading and transition recommendations), Kölner Zeitschrift für Soziologie und Sozialpsychologie 58(1): 79-97.

Kristen, Cornelia and Nadia Granato (2004) 'Bildungsinvestitionen in Migrantenfamilien' (Educational investments in migrant families), in Klaus Bade and Michael Bommes (eds) Migration - Integration - Bildung, IMIS-Beiträge, Heft 23, pp. 123-41. Bad Iburg: Grote Druck.

Lüttinger, Paul and Thomas Riede (1997) 'Der Mikrozensus: Amtliche Daten für die Sozialforschung' (The German Microcensus: Offical statistics in social sciences), ZUMA-Nachrichten 41(21): 19-43.

Marks, Gary N. (2005) 'Accounting for Immigrant Non-Immigrant Differences in Reading and Mathematics in Twenty Countries', Ethnic and Racial Studies 28(5): 925-46.

Müller, Andrea G. and Petra Stanat (2006) 'Schulischer Erfolg von Schülerinnen und Schülern mit Migrationshintergrund: Analysen zur Situation von Zuwanderern aus der ehemaligen Sowjetunion und aus der Türkei' (School success of students with migration background: The situation of immigrants from the former Soviet Union and Turkey), in Jürgen Baumert, Petra Stanat and Rainer Watermann (eds) Herkunftsbedingte Disparitäten im Bildungswesen. Differenzielle Bildungsprozesse und Probleme der Verteilungsgerechtigkeit, pp. 221-255. Wiesbaden: VS Verlag für Sozialwissenschaften.

Müller, Walter and Yossi Shavit (1998) 'The Institutional Embeddedness of the Stratification Process: A Comparative Study of Qualifications and Occupations in Thirteen Countries', in Yossi Shavit and Walter Müller (eds) From School to Work: A Comparative Study of Educational Qualifications and Occupational Destinations, pp. 1-48. Oxford: Clarendon Press.

Müller, Walter, Susanne Steinmann and Renate Ell (1998) 'Education and LabourMarket Entry in Germany', in Yossi Shavit and Walter Müller (eds) From School to Work: A Comparative Study of Educational Qualifications and Occupational Destinations, pp. 143-87.Oxford: Clarendon Press.

Portes, Alejandro and Lingxin Hao (2004) 'The Schooling of Children of Immigrants: Contextual Effects on the Educational Attainment of the Second Generation', Proceedings of the National Academy of Science 101: 11920-7.

Sachverständigenrat für Zuwanderung und Integration (2004) Migration und Integration: Erfahrungen nutzen, Neues wagen (Migration and integration: Making use of experiences. Trying new ways), Jahresgutachten 2004. Berlin: Sachverständigenrat für Zuwanderung und Integration.

Schofield, Janet (2006) Migration Background, Minority-Group Membership and Academic Achievement: Research Evidence from Social, Educational, and Developmental Psychology, AKI-Forschungsbilanz 5, Berlin: Arbeitsstelle Interkulturelle Konflikte und gesellschaftliche Integration.

Schwippert, Knut, Wilfried Bos and Eva-Maria Lankes (2003) 'Heterogenität und Chancengleichheit am Ende der vierten Jahrgangsstufe im internationalen Vergleich' (Heterogeneity and equal opportunities at the end of the fourth grade in the German Federal States and in international comparison), in Wilfried Bos, Eva-Marie Lankes, Manfred Prenzel, Knut Schwippert, Renate Valtin and Gerd Walther (eds) Erste Ergebnisse aus IGLU: Schülerleistungen am Ende der vierten Jahrgangsstufe im internationalen Vergleich, pp. 265-302. Münster: Waxmann. 
Schwippert, Knut, Wilfried Bos and Eva-Maria Lankes (2004) 'Heterogenität und Chancengleichheit am Ende der vierten Jahrgangsstufe in den Ländern der Bundesrepublik Deutschland und im internationalen Vergleich', in Wilfried Bos, Eva-Marie Lankes, Manfred Prenzel, Knut Schwippert, Renate Valtin, Gerd Walther (eds) IGLU: Einige Länder der Bundesrepublik Deutschland im nationalen und internationalen Vergleich, pp. 165-90. Münster: Waxmann.

Stanat, Petra (2003) 'Schulleistungen von Jugendlichen mit Migrationshintergrund. Differenzierung deskriptiver Befunde aus PISA und PISA-E' (Educational achievement of immigrant youth: Descriptive results from PISA and PISA-E), in Jürgen Baumert, Eckhard Klieme, Michael Neubrand, Manfred Prenzel, Ulrich Schiefele, Wolfgang Schneider, Petra Stanat, Klaus-Jürgen Tillmann and Manfred Weiß (eds) PISA 2000: Ein differenzierter Blick auf die Länder der Bundesrepublik Deutschland, pp. 243-260. Opladen: Leske + Budrich.

Stanat, Petra (2006) 'Schulleistungen von Jugendlichen mit Migrationshintergrund: Die Rolle der Zusammensetzung der Schülerschaft' (Educational achievement of immigrant youth: The role of the student composition), in Jürgen Baumert, Petra Stanat and Rainer Watermann (eds) Herkunftsbedingte Disparitäten im Bildungswesen. Differenzielle Bildungsprozesse und Probleme der Verteilungsgerechtigkeit, pp. 189-219. Wiesbaden: VS Verlag für Sozialwissenschaften.

Stanat, Petra, Jürgen Baumert and Andrea Müller (2005) Förderung von deutschen Sprachkompetenzen bei Kindern aus zugewanderten und sozial benachteiligten Familien: Erste Ergebnisse des Jacobs-Sommercamp Projekts (Promoting German language competences of children with migrant and socially disadvantaged background). Berlin: Max-Planck-Institut für Bildungsforschung.

Statistisches, Bundesamt (2006) Leben in Deutschland. Haushalte, Familien und Gesundheit. Ergebnisse des Mikrozensus 2005 (Living in Germany: Households, families, and health. Results of the Microcensus 2005). Wiesbaden: Statistisches Bundesamt.

Vallet, Louis-André and Jean-Paul Caille (1999) 'Migration and Integration in France: Academic Careers of Immigrants' Children in Lower and Upper Secondary School', paper presented at the ESF Migration and Inter-Ethnic Relations in Europe Conference, September, Obernai, France.

CORNELIA KRISTEN is Research Fellow in the Institute of Sociology at the University of Leipzig, Germany. Address: Institut für Soziologie, Beethovenstraße 15, 04107 Leipzig, Germany. [email: Kristen@sozio. uni-leipzig.de]

NADIA GRANATO is Research Fellow in the Institute for Employment Research of the German Federal Employment Agency. Address: Institut für Arbeitsmarkt- und Berufsforschung, Regensburger Straße 104, 90478 Nürnberg, Germany. [email: Nadia.Granato@iab.de] 


\section{APPENDIX: DATA AND VARIABLES}

To analyse the second generation's educational attainment we use the GMC, an annual 1 percent household survey of the population in Germany (Lüttinger and Riede 1997). For our study, we combine all available scientific use files that for each year consist of a 70 percent subsample. The combined dataset covers the surveys from 1991, 1993 and thereafter for each year from 1995 to $2004(N=12)$. We restrict our analyses to respondents living in the western part of Germany because the classic labour migrants and their descendants still mostly live in this area.

Educational attainment is measured with regard to the highest level of general secondary schooling, the Abitur (maturity certificate). Accordingly, we distinguish between individuals who have accomplished the Abitur or are preparing for it (i.e. attending one of the last three years of a track leading to the Abitur) versus individuals who have completed elementary or intermediate general education and are not preparing for the Abitur. A more comprehensive way to capture differences in educational attainment would be to distinguish between the three different levels of secondary education. Unfortunately, for students who attend grades 5-10, the GMC does not allow for an identification of the type of track. Therefore, by setting the lower age limit to 18 , we restrict our analyses to respondents who, at this age, usually have moved beyond grade 10 . To describe the educational attainment of the second generation and Germans (Figures 1 and 2), we focus on young adults aged 18 to 25 at the time of the GMC.

Another drawback of the GMC data is that information on parents' social background (i.e. their educational and occupational attainment) is only available if respondents still live with their parents. Since with increasing age more and more respondents leave the parental household, in the regression models (Figure 3, Tables A1 and A2), we exclude older age groups and restrict the account to 18-year-olds who still live with their parents. ${ }^{1}$

The GMC does not include information on parents' country of birth. Therefore, we use citizenship to identify the different ethnic groups. We assign respondents to the second generation if they have another nationality than German and were born in Germany, or immigrated up until the age of six. Based on citizenship, we further classify them into six groups: Turks, (ex)Yugoslavs, Italians, Greeks, a combined group of Portuguese and Spaniards, and a category for all other ethnic groups. German citizens belong to the reference population. ${ }^{2}$ We use the CASMIN classification to capture parental educational attainment (Brauns and Steinmann, 1999). 'Parental' means that we consider the father's education and, if this information is missing, we refer to the mother's educational attainment. Because there are low numbers of cases available for certain categories, we combine 


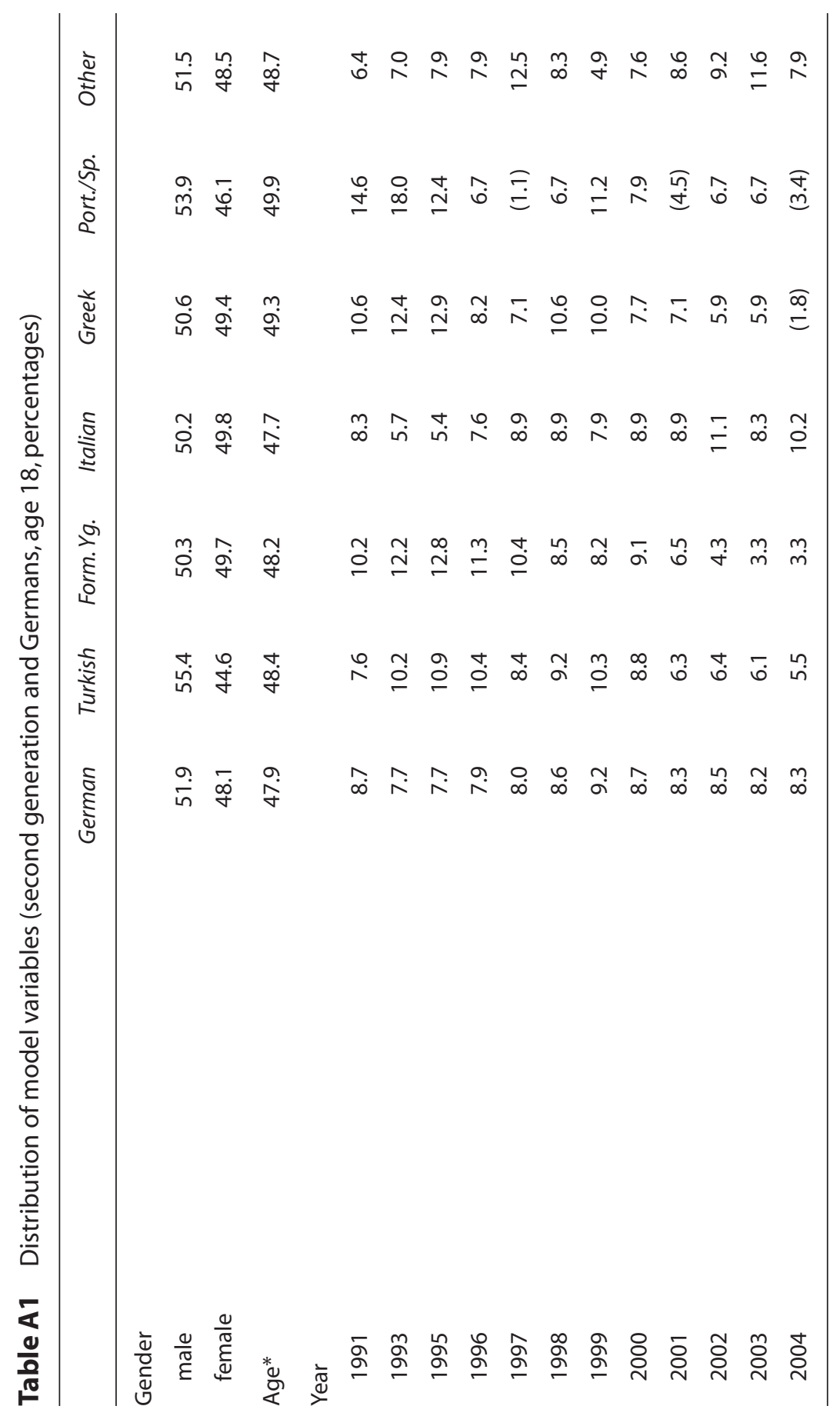




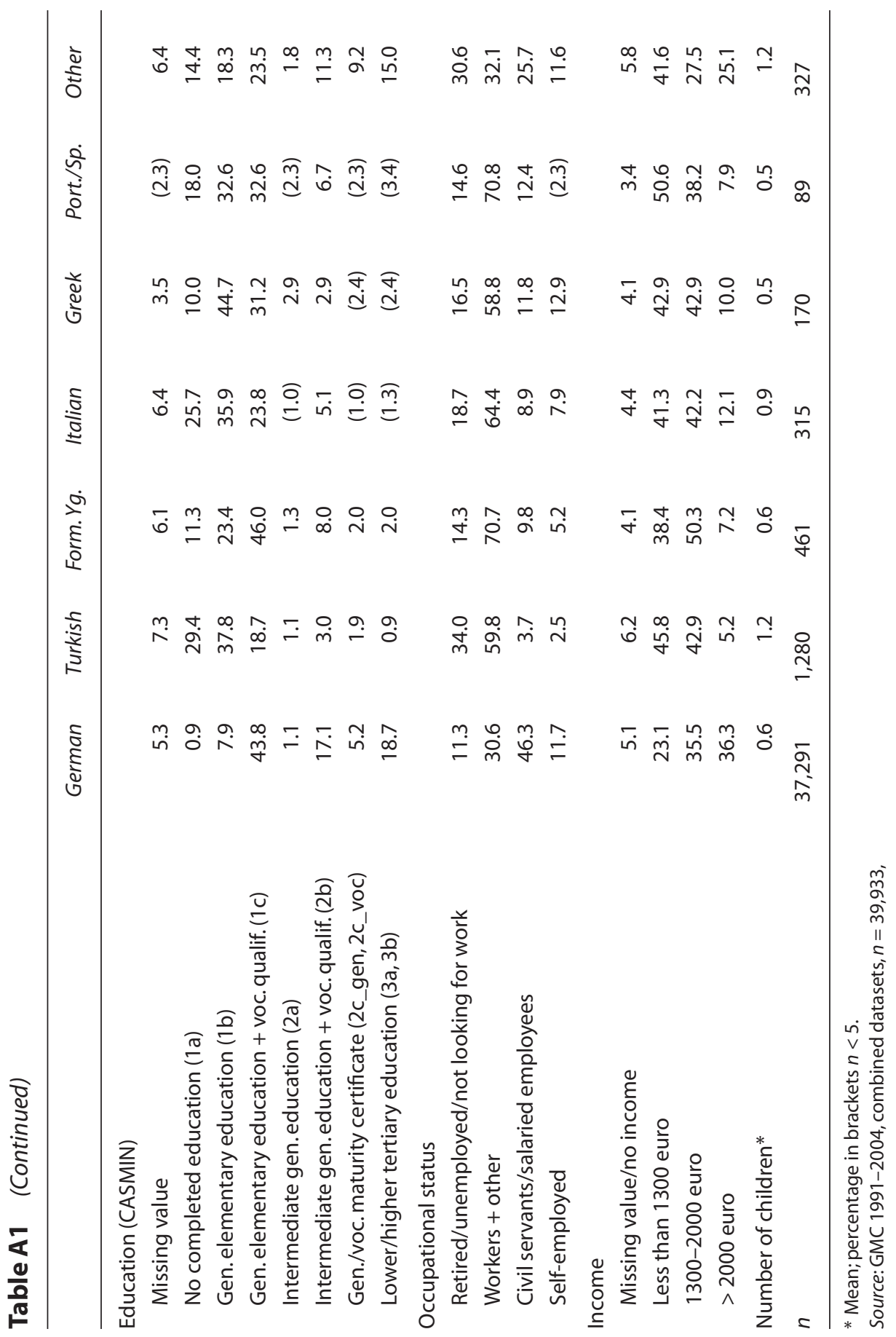


Table A2 Logistic regressions of Abitur

\begin{tabular}{|c|c|c|c|c|c|c|}
\hline & Model 1 & se & Model 2 & se & Model 3 & se \\
\hline \multicolumn{7}{|l|}{$\begin{array}{l}\text { Nationality } \\
\text { ref. German }\end{array}$} \\
\hline Turkish & $-.928^{*}$ & .066 & .026 & .075 & .034 & .075 \\
\hline Former Yugoslavian & $-.742^{*}$ & .105 & .049 & .110 & .085 & .111 \\
\hline Italian & $-1.530^{*}$ & .157 & $-.681^{*}$ & .165 & $-.644^{*}$ & .163 \\
\hline Greek & .252 & .156 & $1.140^{*}$ & .162 & $1.10^{*}$ & .163 \\
\hline Portuguese/Spanish & -.142 & .217 & $.809^{*}$ & .227 & $.797^{*}$ & .223 \\
\hline Other & .166 & .113 & $.496^{*}$ & .126 & $.567^{*}$ & .134 \\
\hline \multicolumn{7}{|l|}{$\begin{array}{l}\text { Gender } \\
\text { ref.male }\end{array}$} \\
\hline Female & $.354^{*}$ & .020 & $.396^{*}$ & .023 & $.397^{*}$ & .023 \\
\hline \multicolumn{7}{|l|}{ Age } \\
\hline (continuous) & $.040^{*}$ & .002 & $.029^{*}$ & .002 & $.029^{*}$ & .002 \\
\hline \multicolumn{7}{|l|}{ ref. 1991} \\
\hline 1993 & $.133^{*}$ & .051 & $.136^{+}$ & .057 & $.135^{+}$ & .057 \\
\hline 1995 & $.199 *$ & .051 & $.112^{+}$ & .057 & $.111^{+}$ & .057 \\
\hline 1996 & $.285^{*}$ & .051 & $.161^{*}$ & .056 & $.159^{*}$ & .056 \\
\hline 1997 & $.285^{*}$ & .050 & $.121^{+}$ & .056 & $.120^{+}$ & .056 \\
\hline 1998 & $.239 *$ & .050 & .074 & .055 & .073 & .055 \\
\hline 1999 & $.333^{*}$ & .049 & $.119^{+}$ & .054 & $.118^{+}$ & .054 \\
\hline 2000 & $.266^{*}$ & .049 & .015 & .055 & .015 & .055 \\
\hline 2001 & $.348^{*}$ & .050 & .080 & .056 & .079 & .056 \\
\hline 2002 & $.318^{*}$ & .050 & .054 & .056 & .053 & .056 \\
\hline 2003 & $.282^{*}$ & .050 & -.013 & .056 & -.016 & .056 \\
\hline 2004 & $.169 *$ & .050 & $-.166^{*}$ & .056 & $-.167^{*}$ & .056 \\
\hline \multicolumn{7}{|l|}{$\begin{array}{l}\text { Education (CASMIN) } \\
\text { ref.gen. elementary education + } \\
\text { voc. qualif. (1c) }\end{array}$} \\
\hline Missing value & & & $1.108^{*}$ & .049 & $1.138^{*}$ & .049 \\
\hline No completed education (1a) & & & $-.253^{*}$ & .092 & $-.446^{*}$ & .104 \\
\hline Gen. elementary education ( $1 \mathrm{~b}$ ) & & & $-.230^{*}$ & .046 & $-.269^{*}$ & .048 \\
\hline Intermediate gen. education (2a) & & & $.643^{*}$ & .103 & $.651^{*}$ & .103 \\
\hline $\begin{array}{l}\text { Intermediate gen. education + } \\
\text { Voc. qualif. (2b) }\end{array}$ & & & $.734^{*}$ & .032 & $.740^{*}$ & .032 \\
\hline $\begin{array}{l}\text { Gen./voc. maturity certificate } \\
\text { (2c_gen, 2c_voc) }\end{array}$ & & & $1.369^{*}$ & .052 & $1.385^{*}$ & .053 \\
\hline $\begin{array}{l}\text { Lower/higher tertiary education } \\
(3 a, 3 b)\end{array}$ & & & $1.786^{*}$ & .038 & $1.795^{*}$ & .038 \\
\hline
\end{tabular}


Table A2 (Continued)

\begin{tabular}{|c|c|c|c|c|c|c|}
\hline & Model 1 & se & Model 2 & se & Model 3 & se \\
\hline \multicolumn{7}{|l|}{$\begin{array}{l}\text { Occupational status } \\
\text { ref. civil servants/salaried employees }\end{array}$} \\
\hline $\begin{array}{l}\text { Retired/unemployed/not looking } \\
\text { for work }\end{array}$ & & & $-.314^{*}$ & .043 & $-.309^{*}$ & .043 \\
\hline Workers + other & & & $-.559^{*}$ & .030 & $-.554^{*}$ & .030 \\
\hline Self-employed & & & .021 & .037 & .022 & .037 \\
\hline \multicolumn{7}{|l|}{$\begin{array}{l}\text { Income } \\
\text { ref. less than } 1300 \text { euro }\end{array}$} \\
\hline Missing value/no income & & & $.571^{*}$ & .055 & $.569^{*}$ & .055 \\
\hline 1300-2000 euro & & & $.274^{*}$ & .033 & $.270^{*}$ & .033 \\
\hline$>2000$ euro & & & $.676^{*}$ & .037 & $.670^{*}$ & .037 \\
\hline $\begin{array}{l}\text { Number of children } \\
\text { (continuous) }\end{array}$ & & & .009 & .014 & .009 & .014 \\
\hline \multicolumn{7}{|l|}{$\begin{array}{l}\text { Interaction nationality } \mathrm{x} \text { education } \\
\text { (continuous) }\end{array}$} \\
\hline Turkish $\mathrm{x}$ education & & & & & $-.150^{*}$ & .042 \\
\hline Former Yugoslavian $\mathrm{x}$ education & & & & & -.057 & .069 \\
\hline Italian $x$ education & & & & & -.151 & .091 \\
\hline Greek x education & & & & & -.206 & .113 \\
\hline Portuguese/Spanish $\mathrm{x}$ education & & & & & -.215 & .138 \\
\hline Other $x$ education & & & & & -.051 & .055 \\
\hline$\chi^{2}$ & 1342 & & 9307 & & 9327 & \\
\hline Pseudo- $R^{2}$ & .024 & & .170 & & .170 & \\
\hline
\end{tabular}

${ }^{*} p<.01 ;{ }^{+} p<.05 ;$ se: standard error

Source: GMC 1991-2004, combined datasets, $n=39,933$.

lower and higher tertiary education into one category as well as the maturity certificate with and without vocational qualification. The remaining categories comprise no completed education, general elementary education, general elementary education with vocational qualification, intermediate general education, and intermediate general education with vocational qualification. In addition, we consider parents' social class position in terms of occupational status. We distinguish between four categories: 'retired/unemployed/not looking for work', 'workers and others', 'self-employed', and 'salaried employees/civil servants'. An income variable that sums up all sources of income indicates the level of available 
financial resources. It distinguishes between 'no income', 'less than 1300 euro', '1300 to under 2000 euro', '2000 euro and above'. We add a missing value category to all these indicators, except for occupational status. Further to the household income, we capture the available financial resources by considering the number of children under the age of 18 who are present in the family. Finally, we include controls for gender, parental age, and the survey year. Table A1 displays the distribution of the various model variables for the different ethnic groups.

\section{Notes}

1 For about 9 percent of all 18-year-olds, information on educational attainment is missing either because the value of the educational variable is missing or because respondents have not yet completed grades 5-10. Among those with valid information on education, 93 percent still live with their parents. One might object that the multivariate results in section 4.2 might be biased, as respondents who still live with their parents may perform better than those not living with their parents. This turns out to be true. However, it does not seem to question our findings with respect to the relative disadvantages of immigrants' children. Further to the fact that most 18 -year-olds still live with their parents, both Germans and second-generation immigrants are positively selected in this regard. Including all respondents at age 18 in the analysis (not shown here) does not affect the ethnic differences displayed in Figure 3 seriously.

2 This group includes respondents with dual citizenship (i.e. those who have German and another nationality) as well as naturalized persons and 'Aussiedler' who cannot be identified in the currently available scientific use files. Minor biases arise if better educated labour migrants and their descendants become German citizens rather than less educated ones because in this case, ethnic differences are overestimated. At the same time, considering that a considerable number of 'Aussiedler' entered the reference population in the late 1990s and that this group is on average less educated than the native-born population, this may lead to an underestimation of ethnic educational disadvantages. However, it is not possible to assess the magnitude of these biases. 